Научна критика

УДК 821.163.41-2.09 Поповић J. С.(049.32)

$811.163 .41 ’ 373(049.32)$

Примљен: 31. 3. 2020.

DOI: https://doi.org/10.46630/phm.12.2020.53

\title{
ЈЕЗИК ДОБРОДЕТЕЉНОГ СРПСКОГ СПИСАТЕЉА
}

(Милена Зорић, Славенизми у раним драмама Јована Стерије Поповића, Матица српска, Нови Сад, 2018)

Један од квалитета по којима се препознаје велики писац јесте да деценијама, чак и вековима након времена у ком је живео и стварао, тумачи и критичари његовог дела и даље имају нешто ново да кажу. Јан Кот је писао да је сума целокупне литературе само о једном Шекспировом делу, Хамлету, позамашнија од прашког телефонског именика. Један од Шекспирових еквивалената са оних поднебља на којима је цветала српска књижевност, без обзира на границе државе условљене политичким и верским начелима, јесте Јован Стерија Поповић.

Огроман значај који су Стеријина дела имала на српску књижевност и културу реципрочан је студијама о његовом раду и литерарним и позоришним иновацијама којима је задужио свој народ. Критичка промишљања бројних тумача баве се Стеријиним драмама из најразличитијих аспеката - од књижевног, историјског, театролошког па до језичког. Године 2018. корпусу литературе о Стерији придружила се књига Славенизми у раним драмама Јована Стерије Поповића Милене Зорић, систематичне проучаватељке дела аутора̂ из предстандардног периода књижевног језика. Милена Зорић је 2016. докторирала на Филозофском факултету у Новом Саду управо на теми „Славенизми у Стеријиним драмама“", транскрибовала је и приредила дела П. Кенгелца, П. Соларића, Ј. Чокрљана, сарађивала је у састављању Речника славеносрпског језика и објавила је више научних и стручних радова из области историје српског књижевног језика предстандардног периода. Из наведеног, јасно да је реч о ауторки која је својим радом и прегнућима стекла високе квалификације када је у питању књижевни, културноисторијски а нарочито језички аспект сагледавања дела писаца попут Стерије. Оно што књигу Милене Зорић чини још значајнијом јесте њен несувопарни приступ теми ${ }^{4}$, те је

\footnotetext{
${ }^{4}$ Примера ради, када говори о суфигираним глаголима које је Стерија користио у анализираним драмама, у контексту објашњења распрострањености суфикса /-ова/ и данас, ауторка наводи популарни глагол лајковати, који је настао на исти начин као и
} 
ова књига, осим што је битна за проучаваоце језика, подједнако важна и проходна онима који се баве књижевношћу.

Студија о славенизмима у раним Стеријиним драмама подељена је на седам целина (,„Увод и теоријско-методолошки оквир истраживања““, „Фонетски аспект славенизама у Стеријиним драмским текстовима“, „Творбени аспект славенизама у драмским делима Јована Стерије Поповића“, „Морфолошки славенизми (партиципи и компаратив)““, „Славенизми у драмском делу Јована Стерије Поповића - заступљеност и функција“, „Речник славенизама у раним драмама Јована Стерије Поповића“ и ,Закључак"). Драме које су обухваћене овом анализом јесу „жалосно позорје“" Невиност или Светислав и Милева (1827), ,јуначко позорје“ Милои Обилић (1828), „весела позорја“ Лажса и паралажа (1830), Зла жена (1838), Покондирена тиква (1838), „трагедија“ Наод Симеон (1830) и „шаљиво позорје““ Тврдица (1837). Како ауторка наводи, ово није први рад о Стеријином језику, али новину коју ова студија доноси у односу на претходне сличне проблематике јесте у томе што је први пут у фокусу корпус славенизама у Стеријиним трагедијама. Феномен славенизама, на чије се флуидно и често непотпуно одређење у досадашњим књижевнојезичким анализама ауторка ослања и које проширује, у овој студији обухвата неколико критеријума (речи преузете из рускословенског и руског језика, славеносрбизми, хибридне форме, оригиналне форме, књишке речи, позајмљенице са фонетским и морфолошким одликама славенизама, ономастичка грађа са фонетским одликама славенизама), али из истраживања искључује сличну грађу која би могла унети забуну (лексика страног порекла, лексика која је током редакцијског периода ушла у лексички фонд српског народног језика). Велики значај ове студије јесте њен језичко-компаративни карактер, што значи да је свака реч која је разматрана у било ком сегменту, независно од тога да ли је испитиван њен творбени аспект, морфологија или нешто треће, упоређена у складу са употребом код других аутора из исте епохе (П. П. Његош, Јаков Игњатовић, Милован Видаковић и сл.), али је испитано и њено значење у другим словенским језицима и редакцијама у којима је била у употреби. Самм речник састоји се од 989 одредница које су дате у складу са начелима лексикографског чланка који подразумева једанаест ставки (одредница, граматичка информација, етимологија итд.), при чему је наглашено да мало лексема садржи све побројане ставке али и да део инвентара подлеже одступањима. Будући да је Стерија писао нереформисаном руском грађанском ћирилицом, ауторка је опрезна при навођењу транскриптивних решења неких лексема, као што је, примера ради, група $/ \check{s} \check{c} /$, пошто начин изражавања неких јунака утиче на њихову карактеризацију, они имају сопствени језички идентитет и чак ни чињеница да је Стеријин језик заснован на поддијалекту шумадијсковојвођанског дијалекта не значи увек да и јунаци говоре у складу са тим како је говорио њихов стваралац.

Стеријин дејствовати. 
Захваљујући уводном поглављу, читаоци се најпре упознају са културном и политичком климом у којој су ницали нови типови језика. Развој српског грађанског сталежа, науке, публицистике, српске грађанске књижевности али и дозвола штампања српских књига у Курцбековој штампарији у Бечу само су неки од индикатора који осликавају значај друге половине осамнаестог века за наш народ. Језичке иновације спроведене упливом руских речи и њиховим утицајем на народни језик учвршћене су захваљујући Доситеју Обрадовићу, који је лексеме књишке провенијенције и термине користио тамо где је у фонду народног језика наишао на празнине. Међутим, неким писцима ове лексеме нису служиле само за попуњавање мисли које су хтели да изразе апстрактним речима којима еквивалент нису нашли у језику којим су се иначе служили, већ су у њима препознали особиту стилску функцију. Како Милена Зорић наводи, до сада није уочена функција славенизама као узвишеног и патетичног језика којим је Стерија имао намеру да се подсмехне својим јунацима и управо на овај начин искарикира њихове животе и прикљученија.

Ауторка уочава да су славенизми у Стеријиним трагедијама најчешће коришћени како би се приказао високи, трагички стил изражавања јунака који „говоре тако без обзира на то шта имају да кажу“ (137). На исти начин оглашавају се и принцеза и служавка, а славенизми овде немају улогу покретача радње. И историја је сведена на декор, мизансцен за одигравање радње, ,а трагичност потиснута типичним инструментаријумом деветнаестовековне мелодраме: невиношћу без заштите, бездушно суровим освајачима, судбинском уклетошћу, племенитим витезовима и њиховим подлим и нечасним опонентима“ (136). Ова дела нису преживела своје време, иако Стерија и у њима на тренутке динамизује језик (поигравање хомонимијом), али Зорић сматра да би „уз интелигентну драматуршку интервенцију и умерену језичку редактуру“ (142) ова дела могла поново да заживе на сцени. Осим што упућује на савремене драматизације Стеријиних дела, њихов квалитет и веродостојност, ауторка се не либи да полемише са савременим позоришним ствараоцима, указујући на неке грешке при интерпретацији Стеријиних интенција 5 .

За разлику од жалосних позорја, у оним веселим и шаљивим славенизми имају вишеструку функцију - њиховом употребом потцртавају се извештаченост, претварање и задње намере јунака који су, најчешће, покретачи радње. Примера ради, Алекса из Лаже и паралаже језик користи као маску: „Када је потребно ‘фарбу променити’ он прикладно славјанствује“( 125$)$, као и

${ }^{5}$ Дејан Мијач је трагедију Наод Симеон оценио као слабу и наивну, где редитељска виртуозност при поставци није могла ништа друго до да се окреће у празно, приписујући аутору свесни пародијски отклон, док Милена Зорић наводи да је овде реч о редитељевом неприхватању „узуса узвишеног стила класицистичке поетике: метафоричан, украшен и патетичан до особеног укидања драмског и у потпуности лишен сликовите полиглосије његових комедија“ (137). 
Јелица, која „чист народни језик сматра недовољно финим и богатим да би изразио мисли и осећања какве може имати једна паланачка фрајлица која је пет година провела на заводу у Бечу“ (135). Ако је језик оптерећен славенизмима, то је показатељ да су на снази марифетлуци јунака који желе да се покажу као углађена господа, достојна титуле и, потенцијално, мираза. Славенизми се на примеру Стеријиних комедија показују и као ефектни изазивачи смеха, најчешће због неспоразума на нивоу звучања (всује - псује, абије - гурабије) или на нивоу хомонимије (закључавати - затварати кључем али и закључивати).

Милена Зорић је указала на колебања при одређивању природе неких речи, односно њиховог основног облика којим би требало да су заступљени у речнику, па тако упозорава да се не може са сигурношћу тврдити да ли поједини придеви имају неодређени вид и предлаже како би са њима у том случају требало поступати. Будући да је сродна студија објављена о Његошевом језику (Светозар Стијовић, Славенизми у у Његомевим песничким делима), ауторка често реферише на одређена језичка разрешења дата у овој књизи, али и подвлачи разлике између ова два писца (примера ради, Стерија, за разлику од Његоша, не употребљава префикс /в - - , али приликом композиције користи суфикс /-лаи/, ког нема код Његоша, а ни у Стеријином Даворју). Творба композицијом у овој студији представљена је прецизно, попут математичке једначине са свим познатим чиниоцима, али и изузецима на која рачуна свака језичка анализа. Сви ови примери уредно су пописани и често представљени као засебне категорије којима је потребно посветити више пажње како би њихово неуклапање у одређени оквир из ког су исклизнули добило објашњење које је често засновано на консултовању грађе и речника њиховог оригиналног порекла.

Славенизми у раним драмама Јована Стерије Поповића јесте ретка систематична и битна анализа за све проучаваоце Стеријиног опуса. Осим што расветљава многе језичке карактеристике Стеријиног дела, тумачи га у контексту књижевности тог доба, са различитих аспеката и у компарацији са досадашњим радовима на овом пољу, Милена Зорић на веома јасан и концизан начин одговара и на важна књижевна питања, посвећујући посебну пажњу карактеризацији ликова и грађењу драмског заплета кроз употребу одређеног језичког идиома.

Маријана С. Јелисавчић ${ }^{6}$

Универзитет у Новом Саду

Филозофски факултет

Одсек за српску књижевност

\footnotetext{
${ }^{6}$ marijanamajche@gmail.com

${ }^{7}$ Истраживање на коме је заснован овај рад спроведено је у оквиру пројекта Аспекти идентитета и ґихово обликовање у српској књижевности (Број 178005), који се, под руководством проф. др Светлане Томин, спроводи на Одсекуза српску књижевност Филозофског факултета Универзитета у Новом Саду, уз финансијску помоћ Министарства просвете и науке Републике Србије.
} 